\title{
LISTENING TO THE ELDER BROTHERS: ANIMALS, AGENTS, AND POSTHUMANISM IN NATIVE VERSUS NON-NATIVE AMERICAN MYTHS AND WORLDVIEWS
}

\author{
Tok Thompson \\ Associate Professor of Anthropology and Communication \\ University of Southern California, USA \\ Email:tokthomp@usc.edu
}

\begin{abstract}
Contrasting with much of Western discourse, Native American myths frequently ascribe world-creating deeds to non-human animals. Further, Native American stories display a remarkable slippage between the worlds of the human and non-human animals, a slippage that continues into worldview, rituals, and everyday life. Using these stories as a starting point, this article seeks to connect the current theoretical movements in posthumanism with those in mythology, in line with Graham Harvey's call for "academic animism", a re-appraisal of the role of non-human agency and culture.

New developments in animal studies have revolutionized the way scholars perceive of non-hominid mental lives and abilities, which has led to challenges to traditional Western beliefs and practices. Many of these new concepts would be old news to Native Americans, whose traditions fundamentally and categorically posit radically different relationships than the non-native. In short, this paper will present a mytho-evolutionary blueprint for broadening our understanding of culture and narrative far beyond the human, yet including the human as well, as part and parcel of cultural life on earth.
\end{abstract}

Keywords: decolonial, mythology, Native American, posthumanism

\section{The Cambridge Declaration on Consciousness}

On this day of July 7, 2012, a prominent international group of cognitive neuroscientists, neuropharmacologists, neurophysiologists, neuroanatomists and computational neuroscientists gathered at The University of Cambridge to reassess the neurobiological substrates of conscious experience and related behaviors in human and non-human animals. While comparative research on this topic is naturally hampered by the inability of non-human animals, and often humans, to clearly and 
readily communicate about their internal states, the following observations can be stated unequivocally:

... the weight of evidence indicates that humans are not unique in possessing the neurological substrates that generate consciousness. Nonhuman animals, including all mammals and birds, and many other creatures, including octopuses, also possess these neurological substrates. (Declaration 2012)

\section{THE CONSCIOUS WORLD}

The beginning of the new millennium witnessed a dramatic growth in scientific knowledge of non-human mental worlds and abilities. Dolphins have individual names for themselves, expressed in whistles (King \& Janik 2013). Hyraxes speak different socially-learned languages (Kershenbaum et al. 2012) Octopi are playful, intelligent creatures who learn quickly from one another (Kuba et al. 2006). Fish use tools (Brown 2012; Bernardi 2012). Such scientific discoveries not only overturn years of scientific thought, but also are in direct contradiction to much of the religious and lay discourse in the Western world regarding "humans versus other life" as well.

Not only must we recognize that animals are "a lot like us", sharing fundamental characteristics heretofore unrecognized, but we must also begin to question the very nature of "us". Such powerful questions tug at accepted definitions of essential words - person, human, animal - while troubling widely accepted ideologies, traditions, language, and beliefs. In animal studies, specialists are now having to confront the study of animal culture, animal communications, and animal mentalities, all of which lead towards the discussion of personhood beyond the human.

In her comprehensive overview of the "animal turn" in recent scholarly discourse, Pauliina Rautio (2013) praises the utility of concept of interspecies articulation, where the focus becomes the connections between the human and non-human, rather than focusing on merely our own species, or on a divide.

From the human-oriented disciplines, the animal turn has been a tectonic shift: "humanities" takes the human as a starting and ending point - if there is anything other, our "animal nature", it is merely cast as a shadow, perhaps as a fault to be overcome. As Tonutti wrote, "we can say that humanism turned its back no nature; it assumed humanitas as a subject of speculation and totally dismissed humanity's natural dimension" (Tonutti 2011: 187). The binary divide between the humanities and natural sciences helps reinforce the seemingly 
intrinsic boundaries between human and animal, yet as these boundaries have proven more fictions than real, the implications have destabilized the underlying organizing principals of "nature versus nurture", or "wild versus cultured". "Cultural studies" is in a similar bind. Culture has long been presumed to be an entirely human affair. Anthropologist Ruth Benedict wrote that "culture is the sociological term for learned behavior .... The degree to which human achievements are dependent on this kind of learned behavior is man's great claim to superiority over all the rest of creation; he has been properly called "the culture-bearing animal"' (1942: 138). Yet now we know most certainly that culture is not the sole province of humans.

Rethinking these basic definitions and their implications forms the backbone of posthumanism. Posthumanism is the general intellectual movement to reexamine what it is to be "human", acknowledging the cultural bases of such ontology. Donna Haraway's canonical works A Manifesto for Cyborgs (2001) and When Species Meet (2007) illustrate the outlines of posthumanist inquiry: work on cyborg identity, artificial intelligence, and, increasingly, animal studies. Within posthuman animal studies, common themes include the human versus the animal; animal minds and awarenesses; domestic versus wild; and the use of animals for human cultural meanings (in such themes as sexuality, race, social inequality, gender, etc.).

Although anthropology is the "study of humankind" by definition, anthropology has increasingly become involved with posthuman questions, particularly in a considered reaction to indigenous accounts and worldviews. An entire 2006 issue of Ethnos focuses anthropological attention into this area. For more on the idea of "multispecies ethnography" and the implications of posthumanism and the animal turn in anthropology, one could see particularly Eben Kirksey and Steffan Helmreich's The Emergence of Multispecies Ethnography (2010), discussing the Cultural Anthropology special issue dedicated to this topic, as well as Alan Smart's Critical Perspectives on Multi Species Ethnography (2014), similarly. An important contribution to this discourse is also Tim Ingold's Anthropology Beyond Humanity (2013).

It is interesting (and slightly ironic) that most of these works deal with animism as human constructions - that is, taking humans as the appropriate site of attention when discussing animism. This may be beginning to change: for example, Colin Scott's Spirit and Practical Knowledge in the Person of the Bear among Wemindji Cree Hunters (2006), takes animism as centered on an essential ontology which allows for non-human agency and personhood - an epistemic de-centering of the agency away from the human, and towards nonhuman personhood: in a word, animism. Here, taking his cue from his Cree 
informants, he notes that such a proposition of animal souls allows for nonhuman agency, even within animism itself. Or, one might say, non-hominids contribute to animism, too. Thus, in his view, animism can be seen as more than a spiritual or religious outlook: instead it is an ontological (and, following this, epistemological) system of understanding the world.

A concurring recent anthropological study is Eduardo Kohn's How Forests Think: Toward an Anthropology beyond the Human (2013). Here, too, the author becomes interested in ontologies, and here too he is interested in Native (South) American ideas of the thinking forests, plants, and animals. According to him, for the Runa, with whom he studies, animism is "grounded in an ontological fact: there exist other kinds of thinking selves beyond the human" (Kohn 2013: 94).

Ontology has deep links with mythology, which is a branch of folklore, yet the discipline of folklore has remained exclusively focused on the human, even while it is increasingly obvious that many of its core subjects (tradition, games, music) are widely shared throughout the animal kingdom. Jay Mechling (1989) first demonstrated the category of inter-special traditions, showing that a "folk group" is not limited to humans. Combining these insights with those afforded by animal studies, and by Scott's view of animism as ontology, we are now in a better position to examine core difference in Native American mythology (enmeshed in animist ontologies), with those of non-Native, Western mythologies, based instead on an anthropocentric ontology. This article seeks to extend posthumanist and postcolonial perspectives utilizing comparative mythologies in investigating our relationship with the non-human world, our own categorical ontology.

There are some inherent difficulties in large-scale comparative mythological studies and associated worldviews. Perhaps the most pronounced is the reluctance of many scholars to admit that there are widespread mythologies and associated worldviews: universalists such as Carl G. Jung and Joseph Campbell (now largely discredited from scholarship; see, e.g., Dundes 2005), argued for universal mythologies, held together by the "collective unconscious". On the other side of the spectrum, anthropologists and ethnologists tended towards site-specific researches and conclusions, and specialists of all sorts focused on cultural minutiae and dense layers of meaning and contestations at the local - even extremely local - levels. Still, mythologists have long been aware that related mythologies do span immense territories, revealing largescale similarities as well as profound differences in different groups (see, e.g., Dundes 1984, p. 270, where he says: "There is no myth that is universal, no myth which is found among all the peoples of the earth... By the same token, there is no myth that is limited to a single culture"). In this article I compare 
the widespread myth associated with Abrahamic traditions, that of the Garden of Eden with its inherently anthropocentric cosmos, with the variety of myths found in Native North America, which tend to feature non-human actors in creating the world. This key conceptual difference in the creation of the world, and of humankind, I argue, grounds resulting key philosophical differences in the role of human versus non-human animals in Native American societies and traditions, contrasted with Abrahamic-inspired ones.

This, then, is a paper juxtaposing Old World and New World systems of thought, as they relate to non-human animals. In doing so, I do not mean to stress a uniformity in either Abrahamic or New World mythologies or philosophies, but rather try to display what I see as a fundamental (as in the structure of the world) disjuncture between the two, a post-colonial and post-humanist look at mythologies and worldviews. Such an investigation is not merely an academic exercise, but, hopefully, one that could lead to a better understanding of current scientific and lay discourse, and to a better understanding of the contours of the wider topic at hand: how to envision our relationship with other species.

This comparative view of the Native American mythology and worldviews with that of Euro-American may provide valuable insights into the benefits of postcolonial theory, being able to learn anew from previously-discounted cultural discourses of knowledge. By nature, such a large comparison will paint the picture in broad strokes, at times doing a disservice to the variety of different traditions in both worlds. Yet I hope that it may still also be able to illuminate critical differences that bear directly and indirectly on the subject of human relations with the natural world.

\section{SACRED NARRATIVES FOR EVERYDAY LIVING}

The categorical differences in human/animal ontology in the categorization of the numinous can be traced to the cosmogonic myths, the sacred stories of how the world (and other things) came to be. Myths explain not only the cosmos, but they also explain one's relation to the cosmos. Myths answer the big questions: What is life? What is thought? What is my place here in the universe? Myths are a sacred charter for our most everyday and mundane actions, as well as for our ritualized ones. ${ }^{1}$

In studying both Native American mythology and traditional culture, one is inevitably struck by the strong sense of connections to other living things animals, plants, even stones and forces of nature. This has spectacular local 
variations, yet the central theme can be found throughout a wide geographic area, part of the larger animism-shamanism area of the Americas and the circumpolar world (see, e.g., Hultkrantz 1991; Hoppál 1987; Brightman \& Grotti \& Ulturgasheva 2012). Animals play active roles in nearly all genres of Native American folklore, from myths and legends to dances and names (see, e.g., Harrod 2000). If I were asked to propose the single most striking difference between Native American cultures and those of Western societies, my answer would have to be in this regard. Although people might feel uncomfortable with widespread comparisons, there is no escaping the wide gulf between how Western and Native American societies portray their kinship with animals. While this emphasis on humans' relatedness (in terms of kinship, but also in terms of ethics, spirituality, and, ultimately, ontology) with other material (especially living) forms can be seen throughout Native American culture (from costumes to art, to song, to dance, and so on), we can find a particular saliency and focus on the core of such ontologies in Native American myths. In nearly all of these, the world, and/or humans, are created by divinities that are explicitly non-hominid.

As Richard Erdoes and Alfonso Ortiz (1984: 3) put it, the stories of "human creation and the bringing of culture reflect in myriad ways a common belief that people are living part of a natural world, brother and sister to the grain and the trees, the buffalo and the bear". While a few major macrotypes have been suggested by Rooth (1984 [1957]), including several found elsewhere in the world, a closer inspection reveals a parade of characters that differ from place to place, yet all inhabiting a similar milieu, a world just prior to ours in which animals regularly talked and acted like people. Animals often turn into people, and vice versa, so it is often vague if it is people or animals being discussed. The transformations are not an aberration, but rather precisely the point. "Blood Clot Man" is sometimes taken as the story of the first man, yet among some he is created by Rabbit (White River Sioux, Erdoes \& Ortiz 1984: 5), and among other by Buffalo (Southern Ute, ibid.: 8). Other Sioux stories claim that the Sioux are descended from Eagle (ibid.: 94), while the Modoc claim Bear as humankind's progenitor (ibid.: 85). White Buffalo Woman (ibid.: 47) is a "messiah" figure who brings culture and civilization to many of the tribes of the great plains: she regularly transforms between Buffalo and woman. "Salmon Boy" among the Haida and many others of the Pacific Coast brings the knowledge of how to treat salmon with respect due to time spent as a salmon (e.g. Gunther 1926), this story setting the stage for many of the most important ceremonies, the World Renewal Ceremony. Among many groups, Grandmother Spider wove together our world (e.g. Erdoes \& Ortiz 1984: 154). Not only animals, but also plants and other natural forces were often included: for example, "Corn Mother" 
is the main creative deity for many groups (e.g. the Penobscot; ibid.: 11) and others, or "Stone Boy" (ibid.: 15) who was created from stones.

The macrotype myth, the "earth-diver", is one of the more widespread creation myths in North America, and frequently features aquatic animals such as ducks (Erdoes \& Ortiz 1984: 89) or muskrats. The world was all water, until the animal dives down to bring up earth. In the crow story "Old Man Coyote Makes the World" (ibid.: 88) the earth is created by earth-diving ducks, yet it is Coyote who stars in the story, creating much of the stuff of the earth, including people. Coyote in this story also created music, and song. Coyote, and his allomotif in the Northwest Raven, is frequently the major creator figure, creating light, as in the widespread story of Coyote/Raven Stealing the Sun and the Moon, which often also figures Eagle as Coyote/Raven's adversary in world change and creation (see, e.g., ibid.: 140, 169, 170). Coyote/Raven figure in many of the most essential creation stories, such as the Caddo's version of the origin of death (ibid.: 470)

But Coyote/Raven is no Jehovah - instead of a perfect, omniscient creator, Coyote is a trickster, falling prey to his own base instincts of greed, or lust, often in humorous encounters in the mythic narrative (e.g. Erdoes \& Ortiz 1984: 335-336). One is left with the distinct impression that this world, rather than being some clock-like heavenly plan, might instead be a bit of a mistake, a bit of a joke.

In many Native American myths, there is a great deal of slippage between the worlds of men and animals. Animals often act and hold councils, even using canoes or tipis, and frequently turn into people. People, likewise, are often revealed to be animals. Interspecial marriages are common, as are their offspring. In the Dena'ina folklore, the animals are people, too: they call humans the "Campfire People", (e.g. Kalifornsky 1991: 41, 71) like the beavers might be called the "Chewing People", and so on. Thus even the word for "person" reflects this distinction: does personhood only refer to homo sapiens? Western discourse tends to say yes. Linguistically, the Dena'ina myths claim the opposite categorical definition - animals are people, too.

Stemming from such widespread and important myths, non-hominid animals are often acknowledged as "Elder Brothers" or some similar title acknowledging their mythic importance, and their existence prior to humans. ${ }^{2}$ Such an outlook reflects an interesting and intriguing spiritual tradition, with ramifications for prevailing notions about the role of animals and other living forms, and our relations to them. 


\section{GOD THE FATHER AND THE THREE LITTLE PIGS}

These tendencies can be easily contrasted with Abrahamic myth. This is salient especially because the Abrahamic faiths of Judaism, Islam, and Christianity are the dominant faiths in over half the human population, and they are the dominant faiths in most of the nations of the world (including the Americas), barring only parts of Asia.

In the myths of the Abrahamic and related faiths, the most common and well-known mythic story is the creation of the cosmos, and the earth, and Man and Woman, as Adam and Eve. It is noticeable that the divine entity appears to resemble a human being, as the bible states that God "created Man in His image" - the implication, and the later iconography, being a male human-looking divinity, who creates the cosmos, the earth, and mankind, as well as rules the cosmos, and the spiritual realm.

One of the most widely known creation stories in the world is the one found in Genesis:

Then God said, "Let us make man in our image, in our likeness, and let them rule over the fish of the sea and the birds of the air, over the livestock, over all the earth, and over all the creatures that move along the ground." (Genesis 1:26, KJV 2004)

In this anthropo- (and andro-)centric tale, a man god rules the universe, and creates mortal man in his image. The only active role of animals in the tale is that of the snake (commonly identified with the Devil/Satan, although the Old Testament does not state this). The snake tricks the pair into eating fruit from the forbidden tree of knowledge, causing their expulsion from Eden by Jehovah. The animal here is clearly the bad guy. ${ }^{3}$

Further, when God banishes Adam and Eve from the Garden of Eden, he states that the land, the plants, and the non-hominid animals are under their control, saying, "Be fruitful, and multiply, and replenish the earth, and subdue it: and have dominion over the fish of the sea, and over the fowl of the air, and over every living thing that moveth upon the earth" (Genesis 1:28, KJV 2004).

The overall narratives of Genesis seem to reflect a patrilineal and patriarchal cultural outlook (everything stems from the man, the patriarch). This outlook accorded well to much of the culture in the Near East, North Africa, and Europe - minority religious traditions notwithstanding. It also helped propagate an explanation of the cosmos in very anthropocentric terms: the spiritual real, heaven, is all about homo sapiens. The rest of this life stuff is ours to do with as we please, without any spiritual significance in the grander scheme of things. 
People are numinous, other life is mundane. In the Abrahamic mythic traditions, the universe is created and controlled by a human-looking male figure ("God made man in his image" (Genesis 1:27, KJV 2004)), for the purpose of mankind. The categorical split is obvious: humankind versus everything else. This is not to say that individuals, and folk traditions, may not disagree with this view, but however compelling their personal appeal might be, the official view from the Abrahamic faiths is that only humans are spiritual beings. As Thomas Aquinas expressed in his Summa Theologica, "He that kills another's ox, sins, not through killing the ox, but through injuring another man in his property" (II-II, q. 64, a.1), while the Catechism of the Catholic Church states that "Endowed with 'a spiritual and immortal' soul, the human person is 'the only creature on earth that God has willed for its own sake'. From his conception, he is destined for eternal beatitude" (Article 1. Man: The Image of God).

The story of the Garden of Eden translated well into Christian Europe, where the common iconography of the fig-leafed couple biting into the fruit of knowledge transformed into a delicious red apple, and the snake representing the Summum Malum, the sum of all evil. This scene is one of the most widespread of the Abrahamic faiths, and it encapsulates the powerful messages transmitted through such mythic tales. As scholars of myth (e.g. Barthes 1995 [1972], Dundes 1984, Lévi-Strauss 1969, Lincoln 1999, Schrempp 2002) have shown, myths do more than offer fantastic stories; myths organize our basic principles about how we organize our cultural lives. The story of Genesis has been taken as a template for many a marriage, and many personal names in the world are derived from the story of Genesis as well. For many people, the story of Genesis further explains the nature of our relation to other life forms: the relationship has been decreed to be one of dominion. ${ }^{4}$

Since the use of agriculture became widespread, agriculture has remained the dominant way of life for most people on the planet, until very recently. The Garden of Eden seems to reflect this agricultural lifestyle, as God decrees that after banishment, humans are to "till the ground" (Genesis 3:23, KJV 2004), which may have been one reason for its easy widespread acceptance. Unlike in the New World, the Old World civilizations domesticated many species. People increasingly saw themselves as lords and masters of nature; herding cattle, irrigating fields, changing the very landscape itself. Domestic animals were good, and under the command of humans; wild animals tended to be bad, threatening human society. If it was all very hard work, one could take comfort in the thought that this was in line with the cosmos: the sacred myth decreed that toiling the fields was God's command. 
Throughout the Middle Ages, this myth provided all the answers needed regarding the beginning of the world: enshrined as one of the most important stories of Christianity, the textual version was held to be literally and factually true, a merging of history and the divine. Stemming from this category of "humans as divine", the relationship between Jesus Christ and humans reflected this model: Christ was seen as a "shepherd" of people. Animals were to people what people were to God. A feudal hierarchy of being was observed, of men as lords and masters of their fields and flocks, while "good servants" of the Lord. ${ }^{5}$

\section{THE “ENLIGHTENED" VIEW OF ANIMALS}

Following the Reformation and the decline of feudal Europe came the Enlightenment, and the rise of science-based learning. In challenging faith-based knowledge, the new philosophies sought to extol the role of the individual and rationality. Although this presented a challenge to the church on many fronts, one aspect that proved harmonious was a continuing anthropocentrism.

The single most influential scholar regarding this issue was doubtless Rene Descartes, whose ideas shaped the modern view of man, now with a critical distinction between the mind and the body. Only humans had a mind, in Descartes' view (see Harrison 1992), and this proved humanity's essentialism. Other living things, therefore, had only a body, and no real sense of thought, or even feelings of pain. For Descartes, and for most of science for the next 400 years, animals in this view were seen as completely separated from hominids, not even sharing basic fundamental qualities like thought processes, emotions, memories, etc. They were instead viewed more or less as "fleshy robots", simply displaying responses to stimuli. This widespread notion continues to influence much of Western culture, as is evidenced from the categorical use of "animals" as meaning "non-hominid animals". Much of Western culture still displays widespread rejection of animal thought, language, and culture, although the scientific evidence establishing each of this has been recently increasingly made apparent. $^{6}$

\section{TALKING ANIMALS ARE FOR BABIES}

In other European genres, we can notice talking animals especially in the märchen, or fairy tales - those traditional narratives told not to discuss true things, but rather for fun and entertainment, and perhaps a bit of pedagogy, and often directed at children. In European traditions, this genre is thickly populated 
with talking animals, from the Three Little Pigs (ATU 124) to Chicken Little (ATU 20c). In the celebrated Aarne-Thompson-Uther Tale Type Index (Uther 2004) the macro-category of Animal Tales takes up the first 299 numbers, while animals also regularly appear in the other categories, particularly in the Tales of Magic macro-category, numbers 300-749. In this category, predicated on non-belief, domestic animals are often portrayed as good, while wild animals, those outside of human dominion and control, are portrayed as bad, as in the Big Bad Wolf. There is a split between "good" domestic animals, and the "bad" wild animals, especially those that may threaten the agricultural livestock, like the "big, bad wolf".

Western society holds anthropomorphized, talking animals as appropriate for children, as any quick review of children's toys, literature, and fashion apparel makes abundantly clear (see, e.g., Dunn 2011). We may see how the idea of talking animals is held to be fantastic, categorically untrue, and appropriate only for the "innocent" age of childhood. Pioneering child psychologist Piaget (1929) described one of the earliest stages of childhood development as the "animistic stage" of psychological development, a terminology still regularly employed.

By extension, we can note how Westerners have historically associated animism with a "childhood stage" of religious development. Talking animals, Western society says, are for children, and societies who have traditions of them, then, such as the Native Americans, are likewise viewed as children. This move employs a long-held metaphor for Native Americans to be "like children", or in a child-like state of cultural evolution. It was yet one more way for the conquering people to denigrate the culture of the conquered, one more example of colonialism. In a clash between two mythic traditions, the militarily successful society trivializes the others' mythic, sacred traditions.

From the Garden of Eden, through Descartes, and into the trivialization of Native American spiritual traditions, the question of the relation between homo sapiens and the other animals has been consistently dismissive, and defensively so, of close links. Indeed, we may note that the science of evolution was noticeably slow to develop in face of an abundance of evidence. It was not until Darwin's Origin of the Species (1859) that a compelling argument was made to establish a model of the past not dependent on the Garden of Eden myth. In the United States, most citizens continue to disbelieve science on this topic, in spite of an overall acceptance of science, generally. ${ }^{7}$ This rate, unparalleled in the developed world, reflects the high rate of religious belief and practice in the United States. I believe that this extreme obduracy to this one issue can be explained at least in part in terms of the power of sacred stories. Many people do not feel comfortable with the idea that we could be "related" to "animals"; hence, for them, evolution must be false. Even our words themselves contain 
this idea: although we know that we are animals, we never use the term in this regard (except as an insult).

We are animals, but we will not say it. We were created out of animals, but we do not feel comfortable believing it. This is the continuing power of myth.

\section{THE VIEW FROM TURTLE ISLAND}

By contrast, as we have seen, throughout Native American mythology, animals play resplendent roles. Indeed, Native American traditions are wholly consonant with the idea of evolution in the general idea that animals were here before us, and that they created us, or our world, long before we arrived on the scene. Further we may remember that this was true long before Western science believed this to be true. Early on, Western science felt secure proclaiming its superiority over Native viewpoints, all the while being wrong on this important point, until the Origin of the Species and the resulting scientific discussion. All the while, there remained, and still remain, many traditions of people learning from animals in Native American discourse, and indeed of animals learning from other animals. There is an intense engagement in the natural world, especially the living world. Animals play central roles in many genres in Native American culture - in stories, dances, clothing, songs, names, and of course the religious observances regarding maintaining the proper relations with the spirit realm, with its many animal denizens. It is difficult to overemphasize the role that animals, in particular, play in Native American cultural traditions (see, e.g., Booth \& Jacobs 1990).

At the heart of it all is animism: the generalized outlook that spiritual forces flow through the material world: all life, certainly, but also things not to be classified as living by Western thought, such as glaciers, wind, and stone. Rather than have a centralized church hierarchy to reflect a canonical text, spiritual authority in animism is more commonly located in the natural world, and the individual's abilities to interact with it, including but not limited to the role of the specialists, the shamans. ${ }^{8}$

In animism, animal spirits are often the creators and teachers of mankind. Such animal spirits are rooted in the role of real animals (the eagle, the mouse, the coyote) but also in the heightened spiritual role of teachers and guides to mankind. Nor should contemporary scholars dismiss such beliefs as all extinct or archaic - many Native Americans continue animist spiritual beliefs and practices (see, e.g., Cassady 2008). 
In animism, human society is seen as dependent on this spiritual relationship with the natural world. Hence, inter-special communication is not only viewed as a distinct possibility, and reality, but even as a necessity. This is why the animals figure so highly in so many genres, including dances and costumes. From rituals to tales, to even personal and clan names, the importance of interspecial communication resounds loudly throughout Native American culture.

For example, hunting in animism is viewed as an inherently spiritual activity, an interaction between two spiritual, soulful beings, and an exchange of flesh, skin, and sustenance. Following this, when spiritual relations with the animals, and the rest of the natural world are good, then so are the material rewards, in the form of animals giving themselves up to humans. Vice versa, when hunting is bad, this means that spiritual relations are bad as well, and very often the animal spirits may be angry at being disrespected, for example when hunters do not offer them appropriate prayers, thanks, and funerary rites. The imposition of the "disrespectful behavior" of non-native culture is held to have significant environmental consequences. John Iniuq, a Caribou Inuit, stated,

Now-days, look around. Animals are insulted. They might go away forever. This can happen. It is not like when I was a child. People don't understand animals any more. People who have to go among animals, out on the land, they still understand. (quoted in Norman 1990: 144-145)

At times these traditions could be mundane, such as accounts of old people near my home area in rural Alaska (Kenai Peninsula) who learned to communicate with ravens. The ravens would help them hunt (the ravens, after all, being cunning scavengers known to guide hunters to their prey). Other times, the accounts of inter-special communications are more spiritual, and visionary, although there may be no clear line between the two. Samaon Autao, a Cree, put it: "In the old times, people and animals talked with each other, just like I talk with my family every day" (Norman 1990: 143).

Anthropologist Rodney Frey writes how the Coeur d'Alene would describe their relations with the non-human world: "Within this web of kinship relationship, the members share in an equality with one another, in what the Coeur d'Alene term unshat-qn" (1995: 41). Such equality is expressed especially by respectful speech and behaviors, for example in asking "permission" to harvest plant life, and in using all parts of the animals hunted.

As Howard Harrod (2000: xii) put it: "Oral memories were rich with examples of how animals gave their bodies to the people, often agreeing to become food because they had established kinship relations with humans". In this way, Harrod states, this reciprocal arrangement contrasts with the non-Native, Euro-American utilitarian views of animals. 
Folklorist Allice Legat (2012) explains how among the Tlicho Dene, the concept of dè signifies not only the environment itself, but also of being aware of one's place in that environment, an elemental form of knowledge for them. Such a knowledge is both physical and spiritual, and therefore necessitates respect, a recognition of the spirit power of the non-human, the souls of animals.

A general notion of reciprocity is shared by many ecocritics and posthumanists, and echoes Tonutti's (2011) call for "articulation". If we know we share an ontology, in what manner do we re-think our relationship to that ontology? In other words, now that we know animals are much more like us than we ever thought, how do we change other related beliefs, outlooks, and even terminology, regarding other living things? In what ways might we re-imagine or recategorize our ontological relationship with the non-human world?

\section{CONCLUSIONS}

There is an explanatory value to myth: in this sense it is not unlike a folk science. At times myths can be productively consonant to scientific explanations, and at times they may seem in direct contradiction. In the Native American traditions, their mythic stories of animals creating the world of the humans is now scientifically known to be largely correct, and in direct contrast to the competing anthropocentric myths of the Abrahamic faiths. We have also seen that Western science was wrong on this for a long time while the Native Americans were right, yet all the Western science and society denigrated their traditional explanations. This is not to state that Native Americans were Darwinists, or employed his notions of biological evolution, but rather that their ontologies tended to concur with Darwin that we are all, indeed, kin.

We may now speak (as good scientists) of animal cultures - that is, socially learned, not innate, patterns of behavior. Animals have words, in languages. Animals have been demonstrated displaying episodic memories, the distinct memory of time and events, and even planning ahead for future events (see Thompson 2018). Not only are we closely related to animals through our bodies, sharing many of the same genes with wolves and even fish, but even our very humanity - ideas of family, of jealousy, of politics, and fairness - is shared with our Elder Brothers. This is a concept that, although well documented, still sits uncomfortably for many people in Western culture. ${ }^{9}$

We have moved the goalposts many times for "what makes humans special", from Man the Tool User, to Man the Language User or Man the Artist. Certainly, there are many things that stand out about humans: we are indeed 
a most remarkable species. Yet, at the same time, we may also notice how much of who we are we find in other species, and how remarkably intelligent (and otherwise gifted!) many other species are as well.

Alongside these scientific advances in our understanding of the remarkable mental worlds of animals has been a general reassessment of the proper moral relations between humanity and other animals. It is unclear what form this will take. There is certainly a radical fringe, some of whom have engaged in violent or other highly controversial actions in the name of animal rights. Yet there is a growing middle ground, as can be witnessed in the increase of animal rights' legislation worldwide. Animal protections of some variety are now standard in the legal systems.

As Donna Haraway (2001: 2271) wrote, "Movements for animal rights are not irrational denials of human uniqueness; they are clear-sighted recognition of connection across the discredited breach of nature and culture". Such "clearsighted recognition" often finds itself in direct contradiction to prevalent current discourses. In 2013 the "Nonhuman Rights Project" filed writs of habeas corpus on behalf of four captive chimpanzees. Merely a few years ago, such an attempt would be laughable, but now it has garnered serious attention from legal scholars as well as ethicists.

Several concepts now current in popular understandings of the natural world also reflect this new discourse. Global warming has cast into stark light the limits, and dangers, of enforcing man's will on the natural world. The increasing environmental stress on the world system is looking particularly ominous, and we may yet have to pay a horrific price for our anthropocentric ways.

That, in itself, should lead us to enquire into other cultural systems and worldviews, particularly of those sensitively attuned to the natural environment now so severely threatened. Even following the concept of anthropocentric utilitarianism, one could argue that it is in our (human) best interest now to pay attention to the planet (an attitude reflected in the growing "Green Theology" of Abrahamic-based environmental approaches). Yet it may also be worth remembering that it is precisely such a philosophical approach that got us into this environmental mess in the first place.

We now talk in terms of ecosystems, and ecological balances, yet these are terms relatively new to our scientific discourse. These concepts largely do agree with Native American mythic traditions, and we can note once more that Native American traditions were very consonant with these terms, including, of course, earlier times when such ideas were not yet formulated in scientific discourse.

This explicit comparison between these two worldviews is not meant to equate folk knowledge with scientific discourse, or to say that folk discourse is "just as good" as scientific discourses. They are, of course, different discourses. 
However, mythic themes can influence a society, including that society's scientific discourses. In the past, Abrahamic myths of an anthropocentric universe created hurdles in understanding the natural world, particularly in terms of its overlap with our own. Myths work at creating ontologies, ontologies which are then carried forth in other discourses, including that of science.

I believe science may learn a great deal from examining traditional Native American mythic traditions, not only about the rest of Native American culture, but also of larger questions of our relation to the rest of the natural world. Investigations into mythology allow us not only to see how categorical ontologies influenced Western discourse, but also, more tantalizingly, how they allow us to witness other ontologies - in this case the animist ontologies revealed in Native American mythology and worldview. It is in this context that we may appreciate Graham Harvey's 2006 article "Animals, Animists, and Academics", where he argues for a re-evaluation of the utility of the concept of animism within academic discourse, as well as Scott's (2006) assertion that the animist outlooks of his Cree informants helped provide them with objectively better wildlife data than was available via Western science.

And, if we admit that the Native American traditions were right about such major issues regarding our relations with other animals, vis-à-vis Western science, about evolution, animal consciousness, animal languages, and other issues, for hundreds of years, then it is at least worth asking, rhetorically, what other issues might they also be correct about. And what of similar views of other minority groups in various locations around the world? Postcolonial science opens itself up to the inclusion of considerations of other schools of thought, other epistemologies, and offers possible avenues of thought out of the dead-end of anthropocentrism.

Postcolonial outlooks also lead us back to the potential of posthumanism: by looking at the overlooked, the under-heard, those with agency and personhood denied, we gain by not only acknowledging and listening to other species, but also by improving our understanding of our own interconnection and relations, and, ultimately, by learning how to use such knowledge to help build a stronger, more sustainable world.

A great deal of scholarly work has been done under the aegis that the concept discussed applies to humans only; new research on a great many topics (ethics, communication, memory, aesthetics, tool use, culture, etc.) has recently shown that this aegis is no longer valid. In seeking to understand the roots of such a worldview, I have contrasted it with Native American traditions, which continue to challenge Western linguistic and cultural assumptions. I have attempted to demonstrate some of the ways in which mythology - those strange 
stories of the formation of the world - profoundly (yet for the most part unconsciously) influences a culture's discourse, even its scientific discourse. I have attempted to do so in order to elucidate a less culture-specific lens through which to view the relations between humans and other living things, and to allow for dialogue, for articulation, between different cultures and different ways of viewing the world: both the Native American, and that of the non-hominid world as well. Postcolonial philosophy, and posthumanism, may in the end be the best of allies, as Western discourse continues to learn from other, previously overlooked, systems of knowledge. The questions that await posthumanist philosophy are daunting yet exciting, stretching into an uncharted territory. What destination they will lead us to is as yet uncertain, but it is clear that our ideas and understandings are headed in vastly new directions, in keeping with the simple goal to better understand ourselves: who we are, and our relations to other living things.

\section{NOTES}

1 For an excellent overview of the topic of myth, see Honko's The Problem of Defining Myth (1984), which lists as "modern theories of myth" several interpretations, including "myth as source of cognitive categories", "myth as form of symbolic expression", "myth as charter of behavior", "myth as legitimation of social institutions", and "myth as religious genre", and the Lévi-Straussian "myth as medium for structure". Schrempp (2002: 2) notes that "myths are recurrently characterized as foundational, primordial, sacred, and theomorphic", while Bruce Lincoln (1999) goes so far as to label myths as "ideology in narrative form", reinforcing the link between worldview (including ontology) and mythology.

2 See, e.g., Beck \& Walters \& Francisco 1977, Brown 1992, Laguna 1995, Brown \& Cousins 2001, Rockwell 2003, McNally 2009.

${ }^{3}$ It is interesting to note that the snake was a widespread symbol for a variety of religious traditions, and particularly a symbol for the idea of reincarnation, perhaps due to the fact that snakes shed their skins (see, e.g., Vaz da Silva 2008).

4 This line of argument has a long and rich history, perhaps in the contemporary era most easily dated to the teachings of historian Lynn White, who put the blame of the ecological crises squarely on the anthropocentric teachings of the Abrahamic mythologies in his classic 1967 Science essay, "The historical roots of our ecological crisis". This essay saw the ecological crises as descended technologically from the industrial age, but philosophically from the medieval Christian worldview.

${ }^{5}$ For an investigation of the views of animals propagated by Islam, see Foltz 2006.

6 The emerging "embodied consciousness" follows epistemological and phenomenological moves in philosophy, which acknowledge biologically mediated experience (e.g., 
Husserl 1989, Merleau-Ponty 2012 [1945]), and comports with many recent studies of the "embodied mind" (e.g., Francisco Varela, Evan Thompson, and Eleanor Rosch's The Embodied Mind (1991), Shaun Gallagher's How the Body Shapes the Mind (2005), Antonio Damasio's Descartes' Error: Emotion, Reason, and the Human Brain (1994), and his Self Comes to Mind: Constructing the Conscious Brain (2010), as well as Evan Thompson's Mind in Life: Biology, Phenomenology, and the Sciences of Mind (2007)). Unlike the "soul-like" image of consciousness (as in Descartes' "homunculus" view, predicating the "mind-body" split), the "embodied mind", with its view of the necessary links between thought and the physical world, needs neither homunculi nor souls.

7 A 2019 Pew Research poll found that only 33 percent of Americans believed that humans evolved in a biological process, when asked directly with one question (this number became 40 percent when asked as a follow-up question) (see Funk 2019).

8 This somewhat glosses over the varieties of spiritual traditions in North America, not all of which had shamans; yet it does convey, I believe, the overall picture of Native American spirituality's intense engagement with the natural world.

9 See, for example, the discussions in Benvenuti 2014, and de Waal 2016.

\section{REFERENCES}

Aquinas, St. Thomas 1920 [1485]. The Summa Theologica of St. Thomas Aquinas. Literally translated by Fathers of the English Dominican Province. Second and revised edition. London: Burns, Oates \& Washbourne. Available at http://www. documentacatholicaomnia.eu/03d/1225-1274,_Thomas_Aquinas,_Summa_ Theologiae_\%5B1\%5D,_EN.pdf, last accessed on 4 October 2019.

Barthes, Roland 1995 [1972]. Mythologies. New York: Hill and Wang.

Beck, Peggy V. \& Walters, Anna Lee \& Francisco, Nia 1977. The Sacred: Ways of Knowledge, Sources of Life. Tsaile, AZ: Navajo Community College Press.

Benedict, Ruth 1942. Race and Racism. London: Routledge \& Kegan Paul.

Benvenuti, Anne 2014. Spirit Unleashed: Reimagining Human-Animal Relations. Eugene: Cascade Books.

Bernardi, Giacomo 2012. The Use of Tools by Wrasses (Labridae). Coral Reefs, Vol. 31, No. 1, p. 39. http://dx.doi.org/10.1007/s00338-011-0823-6.

Booth, Annie L. \& Jacobs, Harvey L. 1990. Ties That Bind: Native American Beliefs as a Foundation for Environmental Consciousness. Environmental Ethics, Vol. 12, No. 1, pp. 27-43. http://dx.doi.org/10.5840/enviroethics199012114.

Brightman, Marc \& Grotti, Vanessa Elisa \& Ulturgasheva, Olga 2012. Animism and Invisible Worlds: The Place of Non-humans in Indigenous Ontologies. In: Marc Brightman \& Vanessa Elisa Grotti \& and Olga Ulturgasheva (eds.) Animism in Rainforest and Tundra: Personhood, Animals, Plants and Things in Contemporary Amazonia and Siberia. New York \& Oxford: Berghahn Books, pp. 1-27.

Brown, Culum 2012. Tool Use in Fishes. Fish and Fisheries, Vol. 13, No. 1, pp. 105-115. http://dx.doi.org/10.1111/j.1467-2979.2011.00451.x. 
Brown, Joseph Epes 1992. Animals of the Soul: Sacred Animals of the Oglala Sioux. Rockport, MA: Element Books.

Brown, Joseph Epes \& Cousins, Emily 2001. Teaching Spirits: Understanding Native American Religious Traditions. Oxford: Oxford University Press.

Cassady, Joslyn 2008. "Strange Things Happen to Non-Christian People": Human-Animal Transformation among the Iñupiat of Arctic Alaska. American Indian Culture and Research Journal, Vol. 32, No. 1, pp. 83-101. http://dx.doi.org/10.17953/ aicr.32.1.14257q67g57mr66k.

Catechism of the Catholic Church. Available at http://www.vatican.va/archive/ccc_css/ archive/catechism/p3s1c1a1.htm, last accessed on 4 October 2019.

Damasio, Antonio 1994. Descartes' Error: Emotion, Reason, and the Human Brain. New York: Harper Perennial.

Damasio, Antonio 2010. Self Comes to Mind: Constructing the Conscious Brain. New York: Pantheon.

Declaration 2012 = The Cambridge Declaration of Consciousness. Available at http:// fcmconference.org/img/CambridgeDeclarationOnConsciousness.pdf, last accessed on 23 September 2019.

Dundes, Alan 1984. Sacred Narrative: Readings in the Theory of Myth. Berkeley \& Los Angeles: University of California Press.

Dundes, Alan 2005. Folkloristics in the Twenty-First Century. Journal of American Folklore, Vol. 118, No. 470, pp. 385-408.

Dunn, Elizabeth 2011. Talking Animals: A Literature Review of Anthropomophism in Children's Books. MA thesis. University of North Carolina.

Erdoes, Richard \& Ortiz, Alfonso (eds.) 1984. American Indian Myths and Legends. New York: Pantheon.

Foltz, Richard C. 2006. Animals in Islamic Tradition and Muslim Cultures. Oxford: Oneworld Publications.

Frey, Rodney (ed.) 1995. Stories That Make the World: Oral Literature of the Indian Peoples of the Inland Northwest as Told by Lawrence Aripa, Tom Yellowtail, and Other Elders. Norman: University of Oklahoma Press.

Funk, Cary 2019. How Highly Religious Americans View Evolution Depends on How They're Asked about It. Pew Reseach Center. Facttank: News in the Numbers, 9 February. Available at https://www.pewresearch.org/fact-tank/2019/02/06/howhighly-religious-americans-view-evolution-depends-on-how-theyre-asked-aboutit/, last accessed on 3 October 2019.

Gallagher, Shaun 2005. How the Body Shapes the Mind. Oxford: Oxford University Press. Gunther, Erna 1926. An Analysis of the First Salmon Ceremony. American Anthropologist, Vol. 28, No. 4, pp. 605-617. Available at https://www.jstor.org/ stable/661297?seq=1\#page_scan_tab_contents, last accessed on 2 October 2019.

Haraway, Donna 2001. A Manifesto for Cyborgs: Science, Technology, and Socialist Feminism in the 1980s. In: Vincent B. Leitch (ed.) The Norton Anthology of Theory and Criticism. New York \& London: W.W. Norton \& Company, pp. 2269-2299.

Haraway, Donna 2007. When Species Meet. Minneapolis: University of Minnesota Press. Harrison, Peter 1992. Descartes on Animals. The Philosophical Quarterly, Vol. 42, No. 167, pp. 219-227. https://doi.org/10.2307/2220217. 
Harrod, Howard L. 2000. The Animals Came Dancing: Native American Sacred Ecology and Animal Kinship. Tucson: University of Arizona Press.

Harvey, Graham 2006. Animals, Animists, and Academics. Zygon: Journal of Religion and Science, Vol. 41, No. 1, pp. 9-19. https://doi.org/10.1111/j.1467-9744.2006.00723.x.

Honko, Lauri 1984. The Problem of Defining Myth. In: Alan Dundes (ed.) Sacred Narrative: Readings in the Theory of Myth. Berkeley: University of California Press, pp. 41-52.

Hoppál, Mihály 1987. Shamanism: An Archaic and/or Recent Belief System. In: Shirly Nicholson (comp.) Shamanism: An Expanded View of Reality. Wheaton, IL: Quest Books, pp. 76-100.

Hultkrantz, Åke 1991. The Drum in Shamanism: Some Reflections. In: Tore Ahlbäck \& Jan Bergman (eds.) The Saami Shaman Drum. Scripta Instituti Donneriani Aboensis XIV. Stockholm: Almqvist \& Wiksell International, pp. 9-27. https:// doi.org/10.30674/scripta.67194.

Husserl, Edmund 1989. Ideas Pertaining to a Pure Phenomenology and to a Phenomenological Philosophy: Second Book; Studies in the Phenomenology of Constitution. Transl. by R. Rojcewicz \& A. Schuwer. Dordrecht, Netherlands: Kluwer Academic.

Ingold, Tim 2013. Anthropology beyond Humanity. Suomen Antropologi: Journal of the Finnish Anthropological Society, Vol. 38, No. 3, pp. 5-23.

Kalifornsky, Peter 1991. A Dena'ina Legacy / K'tl'egh'i Sukdu: The Collected Writings of Peter Kalifornsky. Fairbanks: Alaska Native Language Center.

Kershenbaum, Arik \& Ilany, Amiyaal \& Blaustein, Leon \& Geffen, Eli 2012. Syntactic Structure and Geographical Dialects in the Songs of Male Rock Hyraxes. Proceedings of the Royal Society B: Biological Sciences, Vol. 279, No. 1740, pp. 2974-2981. http://dx.doi.org/10.1098/rspb.2012.0322.

King, Stephanie L. \& Janik, Vincent M. 2013. Bottlenose Dolphins Can Use Learned Vocal Labels to Address Each Other. Proceedings of the National Academy of Sciences, Vol. 110, No. 32, pp. 13216-13221.

Kirksey, S. Eben \& Helmreich, Steffan 2010. The Emergence of Multispecies Ethnography. Cultural Anthropology, Vol. 25, No. 4, pp. 545-576. http://dx.doi.org/10.1111/ j.1548-1360.2010.01069.x.

KJV 2004 = The Holy Bible: King James Version 2004. Dallas, TX: Brown Books Publishing.

Kohn, Eduardo 2013. How Forests Think: Toward an Anthropology beyond the Human. Berkeley: University of California Press.

Kuba, Michael J. \& Byrne, Ruth A. \& Meisel, Daniela V. \& Mather, Jennifer A. 2006. When Do Octopuses Play? Effects of Repeated Testing, Object Type, Age, and Food Deprivation on Object Play in Octopus vulgaris. Journal of Comparative Psychology, Vol. 120, No. 3, pp. 184-190. http://dx.doi.org/10.1037/07357036.120.3.184.

Laguna, Frederica de (ed.) 1995. Tales from the Dena: Indian Stories from the Tanana, Koyukuk, \& Yukon Rivers. Seattle: University of Washington Press. 
Legat, Allice 2012. Walking the Land, Feeding the Fire: Knowledge and Stewardship among the Tlicho Dene. Tucson: University of Arizona Press.

Lévi-Strauss, Claude 1969. The Raw and the Cooked. New York: Harper \& Row.

Lincoln, Bruce 1999. Theorizing Myth: Narrative, Ideology, and Scholarship. Chicago: University of Chicago Press.

McNally, Michael D. 2009. Honoring Elders: Aging, Authority and Ojibwe Religion. New York: Columbia University Press.

Mechling, Jay 1989. "Banana Cannon" and Other Folk Traditions Between Human and Nonhuman Animals. Western Folklore, Vol. 48, No. 4, pp. 312-323. http://dx.doi. org/10.2307/1499545.

Merleau-Ponty, Maurice 2012 [1945]. Phenomenology of Perception. Transl. by Donald A. Landes. Abington \& Oxon \& New York: Routledge.

Norman, Howard (ed.) 1990. Northern Tales: Traditional Stories of Eskimo and Indian People. New York: Pantheon Books.

Piaget, Jean 1929. The Child's Conception of the World. London: Routledge \& Kegan Paul. Available at https://openlibrary.org/books/OL23627514M/The_child\%27s_ conception_of_the_world, last accessed on 26 September 2019.

Rautio, Pauliina 2013. Being Nature: Interspecies Articulation as a Species-Specific Practice of Relating to Environment. Environmental Education Research, Vol. 19, No. 4, pp. 445-457. http://dx.doi.org/10.1080/13504622.2012.700698.

Rockwell, David 2003. Giving Voice to Bear: North American Indian Myths, Rituals, and Images of the Bear. Lanham, MD: Roberts Rinehart.

Rooth, Anna Birgitta 1984 [1957]. The Creation Myths of the North American Indians. In: Alan Dundes (ed.) Sacred Narrative: Readings in the Theory of Myth. Berkeley: University of California Press, pp. 166-181.

Schrempp, Gregory 2002. Introduction. In: Gregory Schrempp \& William Hansen (eds.) Myth: A New Symposium. Bloomington: Indiana University Press, pp. 1-7.

Scott, Colin 2006. Spirit and Practical Knowledge in the Person of the Bear among Wemindji Cree Hunters. Ethnos, Vol. 71, No. 1, pp. 51-66. http://dx.doi. org/10.1080/00141840600603178.

Smart, Alan 2014. Critical Perspectives on Multispecies Ethnography. Critique of Anthropology, Vol. 34, No. 1, pp. 3-7. https://doi.org/10.1177\%2F0308275X13510749.

Thompson, Evan 2007. Mind in Life: Biology, Phenomenology, and the Sciences of Mind. Cambridge, MA: Harvard University Press.

Thompson, Tok 2018. Folklore beyond the Human: Toward a Trans-Special Understanding of Culture, Communication, and Aesthetics. Journal of Folklore Research, Vol. 55, No. 2, pp. 69-92. http://dx.doi.org/10.2979/jfolkrese.55.2.04.

Tonutti, Sabrina 2011. Anthropocentrism and the Definition of 'Culture' As a Marker of the Human/Animal Divide. In: Rob Boddice (ed.) Anthropocentrism: Humans, Animals, Environments. Leiden \& Boston: Brill, pp. 183-202. https://doi. org/10.1163/ej.9789004187948.i-348.44.

Uther, Hans-Jörg 2004. The Types of International Folktales: A Classification and Bibliography. Based on the System of Antti Aarne and Stith Thompson. FF Communications No. 284-286. Three volumes. Helsinki: Suomalainen Tiedeakatemia. 
Varela, Francisco J. \& Thompson, Evan \& Rosch, Eleanor 1991. The Embodied Mind: Cognitive Science and Human Experience. Cambridge: Massachusetts Institute of Technology Press.

Vaz da Silva, Francisco 2008. Archaeology of Intangible Heritage. New York: Peter Lang. Waal, Frans de 2016. Are We Smart Enough to Know How Smart Animals Are? New York \& London: W.W. Norton \& Co.

White, Lynn Jr. 1967. The Historical Roots of Our Ecologic Crisis. Science, Vol. 155, No. 3767, pp. 1203-1207. Available at https://science.sciencemag.org/ content/155/3767/1203, last accessed on 2 October 2019.

Tok Thompson has a $\mathrm{PhD}$ in anthropology from the University of California, Berkeley. He is associate professor of anthropology and communication at the University of Southern California, USA. His main research areas include folklore, mythology, posthumanism, Native Americans, Irish-speaking Ireland, and the Internet. tokthomp@usc.edu 